\section{WE VALUE YOUR FEEDBACK!}

We're all comforted by genuine customer feedback, which is why Dental Sky decided to introduce Trustpilot on their website. Arguably behind every review is a valid customer experience; positive ones give reassurance that you are meeting customer expectations, as well as giving confidence to other customers that your business is built on honesty and transparency. Negative reviews can also be beneficial, as they provide an opportunity to review, assess and if necessary, take steps to improve the overall customer experience.

Trustpilot makes it easy for customers to leave reviews and Dental Sky is delighted with its current score of 9.5 out of 10. Joe Earl, Marketing Manager at Dental Sky, commented: 'We didn't want to rely on a 'gut feel' for how we were doing. Using Trustpilot allows us to solve issues before they become problems. It also tells us exactly what it is that our customers like about us. Ease of use of our website was a key motive, alongside good/transparent pricing and next day delivery with order tracking.'

Work can be complicated, but ordering your sundries shouldn't be. If you want to simplify the process, then visit www. dentalsky.com.

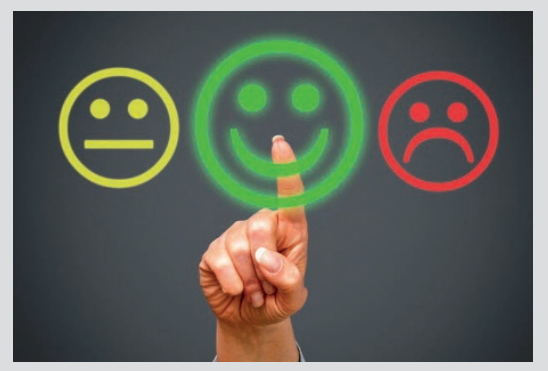

\title{
PARTNERS IN PREVENTION
}

Oral-B is working with the British Society of Dental Hygiene and Therapy (BSDHT) 'First Smiles' initiative. The company has agreed to donate manual kids' toothbrushes and will also provide a power toothbrush for BSDHT members to use as prizes for schools and nurseries who engage in the programme.

Launched in June 2015, the key aim of the programme is to build relationships with nurseries, schools and their local dental practices, so that the fundamental aspects of good oral health can be disseminated to children.

'Oral-B is a natural partner for First Smiles' commented Helen Minnery, President of the BSDHT. 'Oral-B has the tools required to support prevention. Investment in knowledge will pay the best interest, however, children need a good toothbrush to implement the oral hygiene advice given by our members.'

Oral-B uses play and technology to help parents/carers work with children to improve their oral health. Their Disney App, using Disney and Marvel character images, are revealed during 2-minutes brushing time. Children can unlock 16 custom animations and 1,600 rewards, ensuring the app maintains its novelty and transforms the act of brushing into a game.

Making oral care interactive should increase brushing time. Such technology will help to positively influence children's oral health. Professional dietary advice and brushing guidance is crucial to reducing the incidence of carious lesions and lowering DMF levels. To get involved with First Smiles Call 01788575050 or email enquiries@bsdht.org.uk.

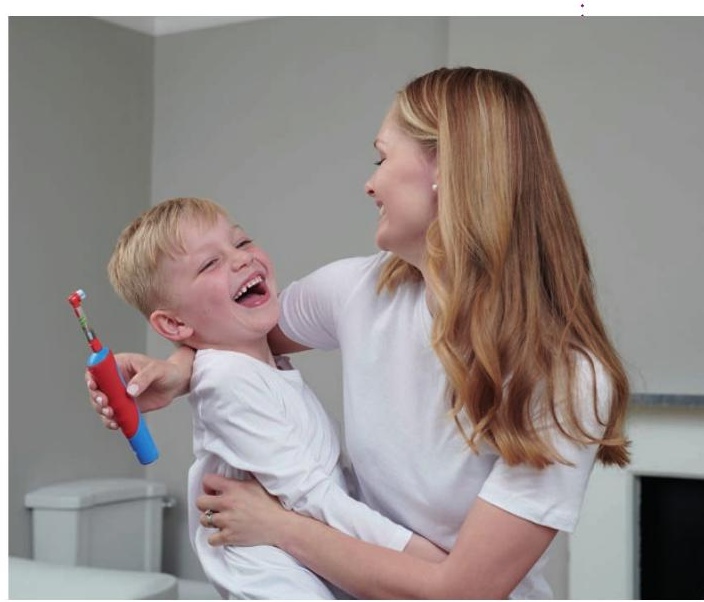

\section{SAVE UPTO 66\% ON PAYSLIP COSTS}

Wagemate offers an automated payroll service that provides complete peace of mind for you and your staff. The team at Wagemate will take care of everything from paying wages to pension contributions, employee enquiries, BACS payments and HMRC documentation, saving you time and hassle. The secure online ePayslip portal also offers a convenient and easy way for both you and your staff to manage finances.

In addition, you could slash your payslip costs by up to $66 \%$, maximising profitability while streamlining your business management processes.

To find out more, contact the friendly team at Wagemate today on 03330102102 or emailinfo@wagemate.com

\section{SHOWCASING}

\section{THE LATEST}

\section{WATER FLOSSING TECHNOLOGY}

The Waterpik ${ }^{\circ}$ team presented the Whitening Water Flosser at BDIA. The Waterpik ${ }^{\circledR}$ Whitening Water Flosser makes it easy to clean hard to reach areas between the teeth and below the gum line. It features an improved grip pressure control and handle hose swivel to help patients to remove debris and harmful bacteria that toothbrushes and traditional floss leave behind. This hi-tech model also has an advanced pressure control system with 10 settings as well as a specially engineered handle that infuses patented whitening technology into the water. Waterpik ${ }^{\oplus}$ Whitening
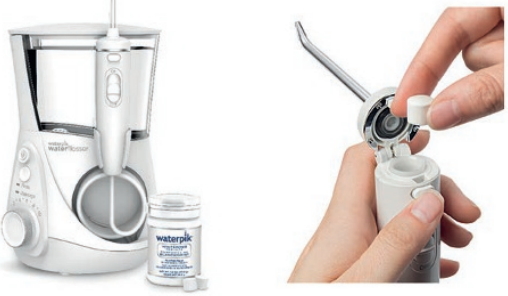

Tablets effectively remove stains and polish away stubborn marks, but are as gentle as regular toothpaste. 